\title{
Tobacco industry efforts at discrediting scientific knowledge of environmental tobacco smoke: a review of internal industry documents
}

\author{
J Drope, S Chapman
}

\begin{abstract}
Study objective-Using tobacco industry internal documents to investigate the use of tobacco industry consulting scientists to discredit scientific knowledge of environmental tobacco smoke (ETS).

Design-Basic and advanced searches were performed on the Philip Morris, Tobacco Institute, R J Reynolds, Brown and Williamson, Lorillard, and the Council for Tobacco Research document web sites, with a concentration on the years 1985-1995. Guildford depository files located on the Canadian Council on Tobacco Control website were also searched. The documents were found in searches undertaken between 1 March and 30 June 2000.

Main results-The industry built up networks of scientists sympathetic to its position that ETS is an insignificant health risk. Industry lawyers had a large role in determining what science would be pursued. The industry funded independent organisations to produce research that appeared separate from the industry and would boost its credibility. Industry organised symposiums were used to publish non-peer reviewed research. Unfavourable research conducted or proposed by industry scientists was prevented from becoming public.

Conclusions-Industry documents illustrate a deliberate strategy to use scientific consultants to discredit the science on ETS.

(F Epidemiol Community Health 2001;55:588-594)
\end{abstract}

The term "passive smoking" was first used in the scientific literature in a paper published in the Lancet in $1974 .^{1}$ The notion that smoking could harm not just smokers, but others around them, radically transformed the ethical basis of public health policy on smoking. ${ }^{23}$ As the science on passive smoking accumulated, it transformed the status of smoking from a matter of individual health risk into a public health problem that could justify interventionist policies designed to protect others from harm. It invited legal action brought by individuals claiming harm. Burgeoning restrictions on the places where smoking was permitted reduced consumption by limiting smoking opportunities for continuing smokers. Workplace smoking bans reduce daily consumption in continuing smokers by over $20 \%,{ }^{4}$ an impact unparalleled by any other tobacco control strategy.

Understandably, the tobacco industry became deeply concerned about the impact of growing public and policy maker concern about passive smoking. In a much cited report published in 1978, the US Roper market research organisation advised its client, the US Tobacco Institute, that passive smoking was "the most dangerous development to the viability of the tobacco industry that has yet occurred". And that "The strategic and long run antidote to the passive smoking issue is [...] developing and widely publicising clear-cut, credible, medical evidence that passive smoking is not harmful to the non-smoker's health." ${ }^{5}$

For over 25 years, the international tobacco industry has given high priority to challenging and attempting to discredit research on passive smoking that concludes it to be harmful. With the Minnesota court creating public access to some 30 million pages of internal tobacco industry documents in $1994^{6}$ unprecedented opportunities have arisen to examine the industry's hitherto secret deliberations on matters of public health importance.

\section{Method}

Industry documents indicate that as early as 1975 the tobacco industry was aware that environmental tobacco smoke (ETS) could be harmful to health. ${ }^{7}$ While there were a small number of studies published in the 1970s, it was not until the 1980 s that research in this area accelerated. By the mid-1980s to late 1980s, studies showing the link between ETS and adverse health outcomes had prompted the publication of major reviews ${ }^{8-11}$ and several governments had begun to implement restrictions on smoking in indoor air areas based for the first time on health, rather than fire hazard considerations. The momentum saw greatly increased efforts by the industry to provide a contrasting view on ETS and steer the issue away from health.

For this reason, we concentrated our document searching between the years 1985-1995. Basic and advanced searches were performed on the Philip Morris, Tobacco Institute, RJ Reynolds, Brown and Williamson, Lorillard, and the Council for Tobacco Research document sites. The Guildford depository files located on the Canadian Council on Tobacco Control Website ${ }^{12}$ were also searched. The documents were found in searches undertaken between 1 March and 30 June 2000. In particular, memoranda and internal reports 
that were not previously public documents have been cited.

\section{Building allies: independent academics and consulting scientists}

In 1986, the Canadian British American Tobacco Subsidiary conducted a two year research project, Project Viking, monitoring public attitudes and knowledge about smoking issues and proposing actions to deal with the growing concerns over ETS. The document stated:

It is highly desirable to control the focus of the debate[ . . . An attack on the credibility of evidence may well provide the rational argument to soften their [smokers' and non-smokers'] attitudes [...] The challenge will be to find a sympathetic doctor who can be demonstrated to take a largely independent stance. ${ }^{13}$

The international industry's ETS network was to become much more extensive than "a sympathetic doctor". The industry sought to hire credentialed scientists who would develop and communicate the results of studies that supported its position that ETS was an insignificant health risk. Tobacco companies quickly decided the issue was serious enough to merit the collaboration of the whole industry. In 1987, the Tobacco Action Committee (TAC), an industry-wide research committee, agreed that:

the most important single issue facing the industry currently was that of ETS. The main question was how we should allocate our resources ... This problem is being tackled by most, if not all, of the major companies and/or trade associations around the world, and it was felt that a degree of worldwide co-ordination was necessary to both complement ongoing work and develop data relevant to the UK $[\ldots]^{14}$

A year later, a note on the Special Meeting of the UK Industry on Environmental Tobacco Smoke showed that Philip Morris (henceforth, PM) took the lead and began to organise research efforts on ETS on an international scale by encouraging partnerships with other companies:

Philip Morris presented to the U.K. industry their global strategy on environmental tobacco smoke. In every major international area (USA, Europe, Australia, Far East, South America, Central America and Spain) they are proposing, in key countries, to set up a team of scientists organized by one national coordinating scientist and American lawyers, to review scientific literature or carry out work on ETS to keep the controversy alive. They are spending vast sums of money to do so ... Because of the heavy financial burden, Philip Morris are inviting other companies to join them in these activities $[\ldots]^{15}$

The PM group of scientists was dubbed internally "Project Whitecoat". The goal of the project was to single out independent scientists who would "go beyond the establishment of a controversy concerning an alleged ETS health risk but to disperse the suspicion of risk". ${ }^{16}$

A 1987 telex from PM's Helmut Gaish an attorney with Covington and Burling who helped develop and coordinate the Whitecoat
Project, illustrates the rush to recruit scientists. The urgency was evident in the lack of coordination between PM and its lawyers:

I had a surprise phone call earlier today from Dr. Bieva in Brussels. He was rather amazed that a certain Dr. Weimberg in Washington should call, asking him exactly the questions that we had already asked him and also offering him a contract. It made him uneasy that so much attention was suddenly focussed upon him from America (we had already introduced him to [law firm] Shook Hardy). We really should not be seen falling over each other when contacting independent scientists. When I gave you the other day-in confidence-our list of "whitecoats", it was precisely with the purpose in mind of avoiding double approaches . . . May I suggest that we agree as quickly as possible among ourselves on who contacts whom $[\ldots]^{17}$

A 1988 US Tobacco Institute (henceforth, TI) document described the rapid building of alliances with academics and consultants. The importance of their credentials is evident:

TI now has 14 academic scientists on ETS; eight have been retained in the last three months. The academics are all faculty members of prestigious universities and medical schools. Their mission is to influence the scientific community's view of ETS science. ${ }^{18}$

The document also described 23 consultants "whose businesses are to market their scientific expertise". ${ }^{18}$ They formed the Scientific Witness Team specialising in ETS, 11 of whose members were exclusively experts on indoor air quality. The TI's concern about the credibility of their consulting scientists was evident in a further discussion of the limitations of using them:

Credibility of the professional consultants is limited in many instances by their willingness to work for tobacco. Academics are not immune from this problem but are less susceptible to it[...] The nature of science prevents them from saying little more than the studies are flawed and the evidence is inconclusive. ${ }^{19}$

The appointment of prominent scientists to the US Environmental Protection Agency's Scientific Advisory Board in 1990 prompted one industry employee to lament the lack of credibility of the industry's own scientists: "The lack of knowledgeable, credible 'white coats' willing to speak for the industry is particularly debilitating." ${ }^{20}$

The TI also sought to add foreign consulting scientists to its network. It was believed by at least one employee that this was a good strategy that would help counter what was described as the "extreme" anti-smoking movement in the US:

This strategy is to bring a "foreign" perspective on ETS science to U.S. journalists through the use of the industry's overseas consulting scientists. Through editorial board briefings and interviews with science and health reporters, these scientists will suggest that the U.S. understanding of science is skewed by anti-smoker media hype, and that the U.S. response to ETS science is extreme and out of step with the rest of the world. ${ }^{18}$

A later PM document (1990) indicates the network building of pro-industry scientists 
continued to grow as did the industry's preoccupation to produce industry supportive data. A report on Smoking and Health Research Activities in Europe stated:

Science and Technology is staffed by 9 academics [ . . . Their mission is centered on environmental tobacco smoke and commissioning researchers and potential authors of scientific papers to produce data publications, or statements that contradict or correct the scientific misinformation about ETS. The S\&T group directly commissions contract work on ETS. These projects are designed to provide data to support the industry's responses to damaging studies in ETS."

Once the industry had found suitable scientists, a corporate strategy was devised, with the scientists being expected to perform a variety of tasks. They were to testify before Congress and other important regulatory bodies; publish articles in scientific literature; submit letters to editors in response to adverse articles in scientific, technical and general audience publications; conduct media "tours"19 each month; and participate in scientific conferences on ETS. Each of these activities sought to increase the credibility of the scientists' research.

At times scientists seemed to be acting more like public relations specialists than scientists. One 1988 BAT memorandum on the issue of "Communication of ETS information" revealed one employee who was anxious about having certain scientists defend their position on ETS in public fearing they might get into trouble if they were too rational:

I believe we should make a distinction between the role of those responsible for communicating at scientific meetings and for communicating to non-specialist audiences. There are several scientists at Southampton, of who both you and Chris Proctor are good examples, who we encourage to cover the former, i.e. specialist meetings. For the others, I see dangers in scientists, who tend to base their arguments on a purely rational approach, getting into "hot water" with potentially aggressive and politically motivated audiences who pursue irrational and often emotional lines of debate. The other danger I see in the nonspecialist fora is that if a scientist strong in ETS know-how becomes involved in discussions that drift toward mainstream smoking issues he has no knowledge base to lean on. For this reason the non-specialist occasions are best handled by Millbank Departments (either Public Affairs or Corporate R\&D). ${ }^{21}$

Another note acknowledges that "there is a danger that in discussion the issue [ETS] might be broadened [... ]" He states his confidence in Chris Proctor in either the specialist or non-specialist forums but agrees that: "Chris should be trained to present the ETS story $[\ldots]^{\prime 22}$

\section{Scientists and lawyers}

PM's organisation of its scientific consultants involved its lawyers playing a central part in determining whom the industry would fund. A PM note on a Special Meeting of the UK Industry on ETS described how coordinators or lawyers were responsible for contacting scientists to see if they were interested in problems of indoor air quality. A BAT participant at the meeting described the process: "Tobacco is not mentioned at this stage. CVs are obtained and obvious 'anti-smokers' or 'unsuitable backgrounds' are filtered out [ . . .] They are asked for a genuine opinion as independent consultants [. . . $]^{15}$ The BAT participant questioned the involvement of lawyers at such a fundamental scientific level, expressing concern about how the industry would be perceived and whether the overt vetting by lawyers would scare off other scientists who might consider working for the industry. ${ }^{15}$

Scientists and independent organisations The building blocks of PM's overall corporate strategy give interesting insight into how the industry plotted to work through third parties to achieve "clout", "power", "credibility", "leverage" and "access" 23 to places they could not otherwise access. The transcript of a workshop given at a PM 1984 Corporate Affairs World Conference illustrates exactly how PM proceeded to use third parties:

[ . . .]First, this whole business of third-party defense depends on creativity. If you are not going to be creative about it [ . . .] you can't be successful. If you are not willing to create vehicles to ride on, to put things together in fact to invent things that did not exist before, coalitions, associations, institutes, seminars, meetings, all kinds of things like that, you cannot be successful. ${ }^{23}$

The industry formed "independent" organisations to affect arm's length perceptions of independent research. In 1988, PM set up the Association of Research on Indoor Air (ARIA), a group of scientists that they had Covington and Burling fund in order to distance themselves from the project. Contrary to the title of the group, it was not formed for research purposes as one document revealed: "It was still being discussed whether the Group will undertake some research (as might be suggested by their title)." ${ }^{24}$

The coordinator of ARIA described how the group fitted into the overall strategy:

Industry $\rightarrow$ Covington Burling $\rightarrow$ ARIA . . . It was suggested that the position of Covington and Burling allows the member of each group to remain independent of the industry, though all know that it is tobacco money that is funding the exercise. $^{24}$

In late 1987, the Center for Indoor Air Research (CIAR) was also created to produce favourable research for the industry in the field of indoor air quality. The CIAR could commission scientists who did not want to be directly affiliated with the tobacco industry but who published studies that strengthened the industry's arguments against regulation of ETS. In 1993, a letter from John Rupp, attorney at Covington and Burlington to Dr Paul Saddler of Imperial Tobacco, Britain, Rupp claimed that "CIAR does not attempt in any way to influence the substance of its grantees." 25 Yet he goes on to write: 
[ . . . In sum, while one might wish it otherwise, the value of CIAR depends on the industry's playing an active role (1) in identifying research projects likely to be of value and (2) working to make sure that the findings of funded research are brought to the attention of decision makers in an appropriate and timely manner. CIAR is a credible and effective vehicle for conducting research that is needed to buttress the industry's position." ${ }^{25}$ (our emphasis)

The tobacco industry also funded special projects based on the recommendations of lawyers rather than scientists through the Center for Tobacco Research (CTR). ACVA Atlantic Study, which was later to become Healthy Buildings International, was a recipient of this funding. In their proposal they hinted that they believed the previous work they had done on workplace indoor air quality, which concluded that ETS had an insignificant effect on indoor air quality, could be applicable to home air quality as well:

The purpose of the attached pilot home air quality study will be to assess the degree of similar outcome in private dwellings, as a precursor to a possible significant study of home air quality. Results of such a study, combined with ACVA and NIOSH results, could demonstrate that ETS has a relative insignificant effect on indoor air quality. ${ }^{26}$

ACVA suggested that the Tobacco Institute-which plainly had an agenda to demonstrate that ETS was harmless-should play an active part in the conduct of the study:

Twelve homes will be selected in three discrete areas of the country giving a total of 36 homes, the selection will be by the Tobacco Institute who will provide names, addresses, phone numbers and contact at each of the homes chosen to ACVA. ${ }^{27}$

In a TI confidential report outlining plans to defeat an attempt by the Occupational Health and Safety Association (OSHA) to establish standards for ETS in the workplace, the proposed research specifies its conclusions before the actual research is undertaken. TI's effort to undermine OSHA is evident when the writer admits the industry is the only one opposing OSHA health measures: "OSHA[ . . .] is unlikely to receive any information supportive of the industry's position on ETS unless the industry itself provides it." 28

The industry worked also to influence independent companies, like the Business Council on Indoor Air (BCIA), which were resistant to being seen to have any affiliation with the tobacco industry but were valuable allies in helping boost the credibility of industry scientists and their focus on ventilation. A 1988 TI document updating the relations between consulting scientists and the BCIA boasted:

[ . . .]BCIA is a small but increasingly prominent trade group which promotes a ventilation or building systems approach-rather than pollutant-by-pollutant source control-to mitigate indoor air pollution. BCIA's membership includes several firms that consult for TI and a few major chemical companies. Tobacco is not and must not be visible in this organization, the
KEY POINTS

- Tobacco industry, industry used scientists, lawyers, independent organidations and symposiums to discredit scientific knowledge of environmental tobacco smoke.

- Environmental tobacco smoke (ETS), industry built up networks of scientists sympathetic to its position that ETS is insignificant health risk.

chemical companies whose involvement is critical to BCIA's credibility have indicated they would not participate if tobacco were involved. We are able to influence BCIA through our consultants and through personal relationships with its executive director. Through BCIA, we are able to present a credible business perspective on indoor air quality issues. ${ }^{18}$

As the transcript from a PM workshop explained:

That's the greatest credibility, your potential enemy [...]To find common ground to find natural friends; to find your natural enemies and if possible, the ways in which you can neutralize them $[\ldots]^{23}$

\section{Indoor air quality}

The industry sought to take the focus away from ETS and health issues. A conference note on the science component of Operation Down Under, one of PM's first comprehensive strategies to combat the idea that ETS was harmful to health, concluded the pitfalls of focusing on health and the benefit of focusing on indoor air quality: "Our position: ETS not shown to be a health hazard to non-smoker. People should focus on whole of indoor air if they are concerned. We cannot say ETS is 'safe' and if we do, this is a "dangerous" statement." 29

The industry proceeded to dodge successfully the health consequences of ETS by developing scientific data to convince policy makers and the world media that ETS was an insignificant component of a much larger problem of indoor air pollution and poor overall ventilation. One 1988 confidential handwritten note read: "IAQ $\rightarrow$ ETS may be a problem, but if so one minor one in a sea of indoor pollution. Ventilation is answer." ${ }^{\text {"30 }}$ The industry understood that the issue could be effectively focused on ventilation rather than cigarettes.

In a 1988 report on ETS and Indoor Air Quality, the ETS working group for BAT submitted seven projects for consideration. None of the studies proposed were on ETS and its health effects. The industry was creating mass amounts of literature on issues that would distract from the harmful effects of ETS on health. Their aim was "to provide a variety of information from several sources which will be available for publication in scientific literature and popular press over the next three years." ${ }^{31}$

A PM document showed the company intended to complicate the issue of health and 
ETS by deflecting the issue from ETS and collecting data on all contributors to air quality. Their objective was to create:

An OSHA standard that regulates Indoor Air Quality (IAQ) (including workplace ETS) without containing separate provisions singling out ETS exposure per se or smoking behaviour/ activity in the workplace. ${ }^{32}$

Positioning ETS as just one component of the much more complex problem of indoor air quality was a clever strategy in that tobacco control activists could not argue that other toxins highlighted by the industry were not dangerous. PM capitalised on this by producing more and more literature on possible confounders of ETS and health.

\section{Symposiums}

In 1988, a PM Corporate Scientific Affairs Plan recommended scientists should not only attend "appropriate conferences", but also become involved in "appropriate scientific organizations and "standard-setting organizations". The plan made the suggestion to "publicize unpublished, but relevant research". ${ }^{33}$ In 1988, the TI outlined that 37 of its scientists were to "actively participate in scientific conferences on ETS.”18

All of the scientists are preparing to participate in the McGill University symposium on ETS [ . . .]Four will present keynote papers at the symposium; these papers will be published as part of the proceedings $[\ldots]^{18}$

Another report stated that the scientists "will present seven of the ten keynote papers at the symposium plus the summary of remarks."19

A 1990 Scientific Advisory Board (SAB) report mentioned sending a total of 77 presenting scientists to an upcoming, unidentified seminar presenting independent scientific appraisal of ETS science for major journalists. ${ }^{20} \mathrm{PM}$ trained scientists to present their findings at air quality and health conferences. These meetings were typically organised by governments and universities and provided opportunities to cultivate scientific credibility. Papers written for symposiums gave the industry the opportunity to publish literature through channels other then peer reviewed journal articles.

However, PM executives became impatient. Conferences were not happening quickly enough, they had no control over the setting, and their scientists were sitting idle, so they began to organise their own:

Here, as elsewhere, we can provide speakers, but the real problem is to find logical and attractive fora for their presentations. (It was that problem which drove us to organizing the meetings ourselves.) To do so permits us to structure the location, occasions and subjects we want, rather than awaiting the accident that someone else might do it. ${ }^{34}$

Bero et al identified 11 symposiums on ETS, including conferences on indoor air quality, published between 1 January 1965 and 31 March 1993 and reported that six were sponsored by the tobacco industry. A comparison of symposium papers and journal articles on ETS suggested that the symposiums were not balanced and tended to present the tobacco industry position on ETS. Journal articles focused mainly on the health effects of ETS while a large proportion of symposium articles were preoccupied with potential confounders like radon, diet or cooking fuel. Most of the industry driven articles on sick building syndrome did not even mention ETS as a component of indoor air. Symposium articles also contained more review articles and articles without statistical analyses. None of the review articles reported the methods used, making it impossible to evaluate selection criteria or the validity of the conclusions. ${ }^{35}$

The tobacco industry has argued that it has been excluded from scientific journals because of publication bias against negative results. Bero et al searched exhaustively for nonsignificant studies on ETS that had been submitted to peer reviewed journals and rejected for publication. They found only a few dissertations and articles and concluded that if these papers exist, then their authors had failed to submit to peer reviewed journals and that there was little evidence of publication bias. ${ }^{36}$

\section{Politicisation of science}

The industry also arranged for some of their consulting scientists to write articles on how its opponents politicised science. A 1988 Tobacco Institute document stated:

[ ...]The consulting academic scientists will work with other credentialed critics to publish articles in scientific journals "reminding" their colleagues in the scientific community of the deficiencies and limitations of their profession, and exhorting them to avoid politicizing their work $[\ldots]^{18}$

In 1993, Canadian John Luik wrote Pandora's box: the dangers of politically corrupted science for democratic public policy to attack the recently released EPA report that had classified ETS as a human carcinogen. When the article appeared in the non-peer reviewed Bostonia it appeared as if it were a completely independent attack on the EPA. However, industry documents reveal that Luik had corresponded regularly with John Legere, chairman of the Confederation of European Community Cigarette Manufacturers (CECCM) on the content of the paper and where it should be published. The article was sent to the Philosophy and Public Affairs fournal for review. While awaiting review, the CECCM decided to send Luik to Japan to deliver the paper at an industry organised scientific symposium to ensure it would be published through the conference monograph.

In preparing for the conference Luik collaborated with Covington and Burling, longstanding counsel to PM, RJ Reynolds, the Tobacco Institute and the Council for Tobacco Research, in writing the article:

Further to the ETS Conference in Tokyo on 2 April 1993, it was reported that J.C. Luik had not been given the opportunity to present the abbreviated paper which he and Covington \& Burling had specially prepared for the conference. ${ }^{37}$ 
The article was thus unable to be published in the conference monograph, thwarting CECCM's plan to circulate his views in ETS debates in Europe. ${ }^{37}$

A preliminary response from the Philosophy and Public Affairs Fournal reviewer asked Luik to consider changes in his paper. In a note to Legere, Luik describes how the journal reviewer described his criticism of the EPA's use of one tailed, $90 \%$ confidence intervals as "manifestly false". ${ }^{38}$ Luik was disturbed by this comment as he felt it was critical to his argument.

\section{Dismissing and hiding unfavourable scientific literature}

Industry documents also show the industry dismissed industry scientist research that did not support its position. In 1981, Takeshi Hirayama published in the $B M F$ what would become a landmark study on ETS and lung cancer in spouses. ${ }^{39}$ While the tobacco industry publicly criticised Hirayama's work, privately it was aware that some of its own consultants had concluded the research was valid. In a 1981 memo, Ernest Pepples, B\&W's vice president of law, wrote:

Dr. Aldokofer who is the Scientific Director of the German Verbandt has committed himself to the position that Lee and Hirayama are correct and Matel and TI are wrong. Adlokofer called Frank Colby at Reynolds and said that Germany had received new data from Japan that confirms the Hirayama work. Adlkofer and Lee and another German associate were all asked to review Hirayama's work and did not pick up on the error picked up by Kastenbaum. They believed Hirayama is a good scientist and that his nonsmoking wives publication was correct [ . . . ] Adlkofer had previously proposed four research products to examine the Hirayama work to be done by the research arm on July 15. Adlkofer was asked how he could continue to support the projects if Hirayama's work was dead. He replied with a strong statement that Hirayama was correct, that the TI knew it and that TI published its statement about Hirayama knowing the work was correct. Subsequently Adlkofer told Colby that unidentified authors would publish in an unnamed publication an article claiming that Hirayama was correct and that TI published its statement while privately acknowledging Hirayama's correctness. Within a few days Adlkofer called again to say that the article was off. ${ }^{40}$

The tobacco industry successfully muzzled this revelation and continued to maintain to the general public that Hirayama's work was flawed.

The cover ups and prevention of research with the potential to produce unfavourable results continued. In 1990, Dr. Adlkofer in Munich proposed a plan for a lifetime animal inhalation study of ETS that was successfully quashed.

PM recently succeeded in blocking Adlkofer's plan to conduct lifetime animal inhalation study of sidestream smoke. ( . . . an INBIFO study has shown that in 90-day inhalation test, no nonreversible changes has [sic] been detected. In a lifetime study, the results were almost certain to be less favorable. Based on the analysis, the other members of the German industry agreed that the proposed study should not proceed. $)^{41}$

\section{Conclusions}

A 1984 US TI document conceded that workplace smoking restrictions were decreasing the overall rate of cigarette consumption:

restrictions [on smoking] are in effect in 37 states and Washington D.C. and may account for as much as 21 percent of the variation in cigarette consumption during 1961-1982, according to a recent study prepared by the Tobacco Merchant's Association. ${ }^{42}$

Industry executives recognised growing studies linking ETS to ill health were only going to increase public smoking restrictions and therefore, decrease consumption. In reaction, the industry quickly began to build a massive international network of scientists who would spread the industry's message that ETS was an insignificant health risk. The industry used lawyers as middlemen to help identify whom to fund, and in some cases, to provide the funding. As a consequence, lawyers played an important part in determining what projects the scientists would, or would not, pursue. The industry trained and sent its scientists to conferences, which they created themselves when the appropriate forum for their message did not exist. They used article submissions at symposiums to make their position known through other channels than peer reviewed journals. They also formed third parties such as "independent" organisations to appear credible but these organisations avoided research on health and its consequences and focused mainly on confounders.

The industry itself admitted that it was unable to say ETS is safe and knew the issue would have a "devastating effect on sales". ${ }^{29}$ Because it could not easily defend its position, it was dependent on credible third parties to steer the issue away from the health consequences of ETS. But as one industry employee pointed out: "[ . . . ]no matter how much the industry may receive and value the endorsement of third parties, unless it can argue its own case its very integrity will be increasingly in question."

Funding: none.

Conflicts of interest: none.

1 Colley JR, Holland WW, Corkhill RT. Influence of passive smoking and parental phlegm on pneumonia and bronchitis in early childhood. Lancet $1974 ; 2: 1031-4$.

2 Chapman S, Borland R, Hill D, et al. Why the tobacco industry fears the passive smoking issue. Int $\mathcal{F}$ Health Serv-

ices 1990;20:417-27.

3 Goodin RE. The ethics of smoking. Ethics 1989;99:574-624

4 Chapman S, Borland R, Brownson R, et al. The impact of workplace smoking bans on declining cigarette consumption in Australia and the USA. Am $\mathcal{F}$ Public Health 1999; 89:1018-23.

5 Roper Organization. A study of public attitudes towards cigarette smoking and the tobacco industry. Washington DC: Roper Organization, 1978

6 Centers for Disease Control and Prevention. About tobacco industry documents. http://www.cdc. gov/tobacco/ industrydocs/about.htm. Accessed 27 May 2000.

7 Third World Conference on Smoking and Health. Passive smoking. http://www.pmdocs.com/getallimg.asp? DOCID $=2501160168$ 17 July 1975

8 US Department of Health and Human Services. The health consequences of involuntary smoking. A report of the Surgeon General. Rockville, MD. US Department of Health and Human Services, Public Health Service, Centers for 
Disease Control, Center for Health Promotion and Education, Office on Smoking and Health, 1986. DHHS tion, Office on Smoking and
Publication no (CDC) $87-8398$.

9 National Health and Medical Research Council. Effects of passive smoking on health. Report of the NH $\mathcal{F}$ MRC Working Party on the Effects of Passive Smoking on Health. Adopted at the 101st Session of the Council, June 1986. Canberra: Australian Government Publishing Service, 1987.

10 Committee on Passive Smoking. Environmental tobacco smoke-measuring exposures and assessing health effects. Committee on Passive Smoking, Board on Environmental Studies and Toxicology, National Research Council. Washington: National Academy Press, 1986.

11 Fourth Report of the Independent Scientific Committee on Smoking and Health. (Chairman: Sir Peter Froggatt). London: HMSO, 1988.

12 Canadian Council on Tobacco Control. Guildford papers http://www.cctc.ca/ncth/guildford/

13 The Canadian Tobacco Papers: a selection of documents related to the Canadian Tobacco Industry. Project Viking, 1980s. http://www.tobaccopapers.org/index/Marketing \%20 \%20ProjectViking.htrr

14 Imperial Tobacco Limited TAC Research Committee. Draft document for discussion 22 400113687/3693 December 1987.

15 Note on a Special Meeting of the UK Industry on Environmental Tobacco Smoke: London http:www.pmdocs.com/ gettallimg.asp?DOCID=401247331 17 February 1988

16 Gaish H. The European counterpart to "Operation Downunder" and the role of S\&T PME. http:// www.pmdocs.com/getallimg.asp?DOCID $=2501474278$ / 428021 February 1988

17 Gaish H. Organization of contacts with whitecoats. Telex to JP Rupp, Covington and Burling. http://www.pmdocs.com/ getimg.asp?pgno $=0 \&$ start $=0 \&$ bool $=$ Whitecoats $\&$ docid $=$ 202354253416 November 1987.

18 Public smoking programs of the Tobacco Institute. Consulting scientists on ETS and indoor air quality. http:// scientists on ETS and

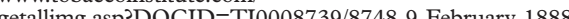

19 Public smoking issue. Consulting scientists on ETS and IAQ. http://www.tobaccoinstitute.com/

getallimg.asp?DOCID=TIDN0003162/3164 27 October.

20 Communications Recommendations/SAB. http://www. pmdocs.com/getallimg.asp?DOCID $=2021181194 / 1195$ 1990.

21 Heard A. Memorandum to Dr RR Baker. British-American Tobacco Company Ltd. 4013537348 June 1988.

22 Binns R. Note to Mr AL Heard. Communication of ETS information. British American Tobacco Company. 401353733 29 June 1988

23 Blake J, Dowling J, Florio D, et al. Workshop - Dealing with the issues indirectly: constituencies. http://www.pmdocs.com/ getallimg.asp?DOCID=2025421934/2000 13 September 1984 .

24 Proctor CI. A presentation by ARIA. Green's Restaurant. London 25th October 1988. 400974548/4550 31 October 1988.
25 Rupp J. Privileged and confidential attorney's work product. Letter to Dr. Paul Sadler, Imperial Tobacco Limited. Letter to Dr. Paul Sa http://www.pmdocs.com/ 26 Hoel D. Shook, Hardy and Bacon. Re:ACVA Atlantic Inc. Proposal. Brown \& Williamson 52102886227 June 1985

27 Robertson G. ACVA Atlantic Inc. Residential inspectionindoor air pollution. Brown and Williamson 5210288642 May 1985. 28 OSHA Projects. Confidential report. http://www.
tobaccoinstitute.com/getallimg.
asp?DOCID=TIDN00 10141/0144 (date not available.)

29 Project Down Under conferences notes. http://www.pmdocs com/getallimg.asp?DOCID $=2021502102 / 213424$ June 1987.

30 Handwritten confidential note. http://www.tobaccoinstitute com/getimg.asp?DOCID=IIDN0002953/ 2955\&PGNO=DUN00208. 08\&am 1988.

31 ETS and indoor air quality. Guildford Files 4001136202 August 1988

32 Proposed action plan for OSHA IAQ/ETS rulemaking. http://www.pmdocs.com/getallimg.asp? 2024699073/9076

33 Corporate scientific affairs plan. http://www.pmdocs.com. getallimg.asp?DOCID $=20230127421991$

34 Philip Morris revised 93 budget: European consultant program. http://www.pmdocs.com/getimg.asp?pgno=0\&start $=$ $10 \&$ bool $=$ parrish $\% 20$ and $\% 20$ work $\% 20$ product $\% 20$ and $\% 20$ health $\&$ docid $=2028398173$ $8177 \&$ docnum $=1513$ November 1992.

35 Bero L, Galbraith A, Rennie D. Sponsored symposia on environmental tobacco smoke. $\mathcal{F} A M A$ 1994;271:612-17.

36 Bero L, Glantz S, Rennie D. Publication bias and public health policy on environmental tobacco smoke. $\mathscr{f} A M A$ 1994;272:133-6.

37 The Confederation of European Community Cigarette Manufacturer Limited (C.E.C.C.M.) working group on smoking at the the workplace and in the public places. Minutes of the meeting of the corporate members' subutes of the meeting of the corporate members sub2025495368/5374 9 June 1993.

38 Legere JJC. Luik's paper for publication. http://www. pmdocs.com/getallimg.asp?DOCID $=2024215189 / 51909$ November 1993.

39 Barnes D, Hanauer P, Slade J, et al. Environmental tobacco smoke: the Brown and Williamson documents. $7 A M A$ 1995;274:248-53.

40 Wells J. Re: Smoking and health-Tim Finnegan. Memo to E Pepples, 1825.0124 July 1981

41 Smoking and health research activities in Europe. http:// www.pmdocs.com/getallimg.asp?DOCID $=2023223372 /$ 33831990

42 Workplace smoking restrictions: communications and lobbying support program. http://www.tobaccoinstitute.com/gettallimg. asp?DOCID=TIFL0504808/4834 February 1984

43 Blackman LCF. The credibility of the industry stance. http://outside.cdc.gov:8080/BASIS/ncctld/web/mnimages/ DDW?W=DETAILSID=762 May 1980. 